\title{
Atklātības principa nodrošināšana valsts un pašvaldību iepirkumos
}

\author{
Dr. iur. Anatolijs Kriviň̨s \\ Daugavpils Universitāte, Tiesību katedra, Latvija \\ anatolijs777@gmail.com
}

\section{Kopsavilkums}

Darba mērḳis bija analizēt atklātības principu publiskajā iepirkumā Latvijas Republikā. Pētijums ir balstīts uz normatīvajiem aktiem (tostarp uz Publisko iepirkumu likumu), tiesu judikatūru un Iepirkumu uzraudzības biroja Iesniegumu izskatī̌sanas komisijas lēmumiem. Pètījuma rezultātus var izmantot gan teorētiḳi, gan arī iepirkumu praktiḳi.

Atslēgvārdi: publiskais iepirkums, atklātības princips.

\section{levads}

2017. gada 1. martā stājās spēkā jaunais Publisko iepirkumu likums, ar kuru tika pārṇemtas Eiropas Parlamenta un Padomes Direktīvas 2014/24/ES (2014. gada 26. februāris) par publisko iepirkumu prasības un atceltas Direktīvas 2004/18/EK prasības.

Atklātības princips publiskajos iepirkumos ir cieši saistīts gan ar informācijas uzkrāšanu (fiksēšanu), gan arī ar informācijas plūsmas nodrošināšanu (paziṇošanu, informēšanu). Dalot publisko iepirkumu secīgos posmos (darbības pirms iepirkuma procedūras izzinošanas, iepirkuma norise, rezultātu paziṇošana, pārsūdzība, iepirkuma līguma slēgšana, iepirkuma līguma izpildes kontrole), ir iespējams sistematizēt atklātỉbas principa nodrošināšanas paṇēmienus. Publisko iepirkumu likumā inkorporētais atklātuma princips paredz, ka publiskajos iepirkumos veicamajām darbībām jānotiek pēc iespējas atklāti, lai uzlabotu lēmumu pienemšanas procesa pārredzamību un uzlabotu sabiedrības piekḷuvi informācijai, tādējādi apstiprinot iestāžu demokrātisko būtîbu un sabiedrības uzticību valsts pārvaldei.

Padarot pieejamu informāciju par lēmumu pienemšanas procesu un noslēgtajiem darījumiem, informācijas atklātība ierobežo ierēdṇu iespējas iesaistīties negodīgos darījumos, rada ievērojamus šḳēršlı valsts iestāžu darbiniekiem iesaistīties pretlikumīgos darījumos un iedzīvoties, piesavinoties vai nevajadzīgi izšḳērdējot valsts īpašumu 
(Sabiedrības par atklātību Delna pētījums, 2000). Publiskajos iepirkumos atklātības princips ir īstenojams, nodrošinot vairāku informācijas elementu publisko pieejamību, piemēram, publiskojot iepirkuma procedūras dokumentāciju ar izvirzìto prasību klāstu un ziṇas par iesniegto piedāvājumu atvēršanu, sniedzot informāciju par pieṇemtajiem lēmumiem.

Darba mērḷis - izanalizēt atklātîbas principa nodrošināšanas mehānismu valsts un pašvaldību iepirkumos Latvijas Republikā.

Materiāls un metodes - normatīvā regulējuma analīze, tiesu judikatūras atlase un analīze, Iepirkumu uzraudzības biroja Iesniegumu izskatīšanas komisijas lēmumu atlase un analīze. Jāṇem vērā, ka prakses piemēri, kas sniegti šajā rakstā, atbilst publisko iepirkumu regulējumam, kas bija spēkā konkrētajā brīdī.

\section{lepirkumu procedūru protokolēšana}

Visos posmos - no iepirkuma komisijas izveides brīža līdz iepirkuma līguma noslēgšanai - ir jānodrošina iepirkuma procedūras gaitas protokolēšana.

Jaunā Publisko iepirkumu likuma, kas stājās spēkā 2017. gada 1. martā, 40. panta pirmajā dạ̦ā noteikts, ka pasūtītājs nodrošina iepirkuma procedūras katra posma dokumentēšanu un šã likuma 9. un 10. pantā minēto iepirkumu dokumentēšanu, kā arī dokumentē iepirkuma procedūru, kas noris, izmantojot elektroniskos līdzekḷus. Atbilstīgi 40. panta trešajai daḷai protokoli, kas atspoguḷo iepirkuma norisi, ziņojums, iepirkuma procedūras dokumenti, izn,emot piedāvājumus un pieteikumus, ir vispārpieejama informācija.

Ieskatam piemērs no Iepirkumu uzraudzības biroja Iesniegumu izskatī̌̌anas komisijas prakses par protokolēšanas kārtību un apjomu (Iepirkumu uzraudzības biroja Iesniegumu izskatīšanas komisijas 2015. gada 10. februāra lēmums Nr. 4-1.2/15-31): "Iesniedzējs norādỉja, ka iepirkuma komisijas protokoli atspoguḷo tikai iepirkuma procesu attiecībā uz iesniedzēju, kas ir būtisks atklātības principa pārkāpums, kas paredz, ka visiem iepirkuma procedūras dokumentiem, izṇemot piedāvājumus, ir jābūt vispārpieejamai informācijai. Par iepirkuma dokumentācijas izsniegšanu iesniedzējs uzskata, ka pasūtītājs ir būtiski kavējis Konkursa noslēguma ziṇojuma izsniegšanu, kā rezultātā iesniedzējs visu nepieciešamo informāciju saṇēmis tikai pēc iesnieguma iesniegšanas termiṇa beigām. Tāpat iesniedzējs uzskata, ka pasūtītājs izsniegtajos iepirkuma komisijas sēžu protokolos nav atspoguḷojis visu likumā noteikto informāciju, tādējādi pārkāpjot atklātības principu.

Iesniegumu izskatī̌̌anas komisija konstatēja, ka iesniedzējs ir pieprasījis papildu informāciju, t. sk. arī Konkursa ziņojumu, 2015. gada 14. janvārī. Prasīto informāciju pasūtītājs nosūtỉja iesniedzējam 2015. gada 19. janvārī, t. i., trešajā darbdienā.

Atbilstoši Publisko iepirkumu likuma 83. panta otrās daḷas 2. punktam iesniegumu par pasūtītāja vai iepirkuma komisijas darbību iepirkuma procedūras norises laikā var iesniegt 15 dienu laikā pēc dienas, kad paziņojums par iepirkuma procedūras 
rezultātiem nosūtīts attiecīgajai personai pa pastu. Atbilstoši Administratīvā procesa likuma 43. panta otrajai daḷai, ja termiña pēdējā diena ir sestdiena, svētdiena vai likumā noteikta svētku diena, termiṇa pēdējā diena ir nākamā darba diena. Iesniegumu izskatīšanas komisija secina, ka, tā kā paziṇojums par rezultātiem pretendentiem tika nosūtìts 2015. gada 9. janvārī, tad iesnieguma iesniegšanas termiņ̌̌ IUB (Iepirkumu uzraudzības birojam) bija 2015. gada 26. janvāris, līdz ar to nav pamatots iesniedzēja apgalvojums, ka iesnieguma iesniegšana pēc visas pasūtìtāja nosūtìtās informācijas saṇemšanas vairs nebija iespējama.

Vienlaikus iesniedzējs nebija kavēts lūgt procesuālā termiṇa pagarināšanu vai atjaunošanu atbilstoši Administratīvā procesa likuma 48. panta pirmajai daḷai, ja tas uzskatīja, ka informācijas izsniegšanas kavēšana par vienu darbdienu tam liedza adekvāti sagatavot iesniegumu, taču iesniedzējs šo iespēju nav izmantojis.

N̦emot vērā minēto, Iesniegumu izskatīšanas komisija nekonstatē, ka ziṇojuma izsniegšanas termiņa kavējums būtu radījis reālu iesniedzēja tiesību ierobežojumu, kas būtu par pamatu atcelt iepirkuma komisijas pieṇemto lēmumu par konkursa rezultātiem.

Attiecībā uz iesniedzēja argumentu par iepirkuma komisijas sēžu protokolos un ziṇojumā iekḷaujamo informāciju Iesniegumu izskatīšanas komisija secināja, ka paziņojot par līguma slēgšanu un informējot kandidātus un pretendentus, pasūtītājs nav tiesīgs atklāt informāciju, kuru tam kā komercnoslēpumu vai konfidenciālu informāciju nodevuši citi piegādātāji. Arī Publisko iepirkumu likums tieši nosaka, ka pretendentu piedāvājumi nav vispārpieejama informācija.

Papildus tam ir noteikts, ka piedāvājumu vērtēšanas kopsavilkums un pamatojums piedāvājuma izvēlei ir ziṇojumā norādāms, ja par piedāvājumu izvēles kritēriju noteikts saimnieciski visizdevīgākais piedāvājums. N̦emot vērā, ka piedāvājuma izvēles kritērijs nebija saimnieciski visizdevīgākais piedāvājums, bet gan piedāvājums ar viszemāko cenu, Iesniegumu izskatī̌̌anas komisija uzskata, ka pasūtitājs bija tiesīgs izsniegt iesniedzējam iepirkuma komisijas sēžu protokolu un ziṇojumu norakstus, neatspoguḷojot informāciju, kas attiecas uz citu pretendentu piedāvājumu detalizētu vērtēšanu. N̦emot vērā minēto, Iesniegumu izskatî̌sanas komisija secināja, ka iesniedzēja iesniegums šajā dạ̦ā nav pamatots."

\section{Informēšana par iepirkuma procedūras prasībām}

Veicot publisko iepirkumu, iespējamie piegādātāji noteikti ir jāinformē gan par iepirkuma priekšmetu, gan par pretendentu atlases prasībām, gan par prasībām, kas ir izvirzītas piedāvājuma sagatavošanai, gan arī par piedāvājuma izvēles kritēriju.

Ja par piedāvājuma izvēles kritēriju noteikts saimnieciski visizdevīgākais piedāvājums, katrs iepirkuma komisijas loceklis piedāvājumu vērtē individuāli pēc visiem iepirkuma procedūras dokumentos norādītajiem vērtēšanas kritērijiem. Par saimnieciski visizdevīgāko piedāvājumu atzīst to piedāvājumu, kas, apkopojot individuālos vērtējumus, ieguvis visaugstāko vērtējumu. 
Ir svarīgi, lai šie kritēriji, pirmkārt, tiktu laikus publiskoti (t. i., tiktu publicēti vienlaikus ar iepirkuma procedūras dokumentāciju); otrkārt, lai šie kritēriji būtu precīzi izteikti un saprotami piegādātājiem; treškārt, lai šie kritēriji būtu samērīgi un nediskriminējoši.

Jāṇem vērā, ka prezumpcija attiecībā uz vērtēšanas kritēriju preventīvu publiskošanu nav visaptveroša. Piemēram, no Eiropas Savienības Tiesas sprieduma lietā Nr. C-532/06 Emm. G. Lianakis $A E$ u. c. izriet, ka pēc piedāvājumu iesniegšanas termina beigām metodologiiju (t. i., vērtēšanas kritēriju vērtēšanas diapazona skaidrojumu) var noteikt, ja pieškiršanas kritēriju punktu iedalījums ir ietverts iepirkuma dokumentācijā pirms piedāvājumu iesniegšanas, proti, vērtēšanas kritērijos iegūstamais punktu īpatsvars, kā arī vērtēšanas kritērijos noteiktais vērtēšanas diapazons ir noteikts konkursa nolikumā un vērtēšanas kritēriju relatīvā nozīme pretendentiem ir zināma (Eiropas Savienības Tiesas 2008. gada 24. janvāra spriedums lietā Nr. C-532/06 Emm. G. Lianakis $A E$ u. c. pret Dimos Alexandroupolis u. c., 43. paragrāfs), precīzi ievērojot Eiropas Savienības Tiesas spriedumā lietā Nr. C-331/04 ATI EAC Srl e Viaggi di Maio Snc noteiktos trīs nosacijumus:

1) netiek grozìti līguma dokumentos vai konkursa paziṇojumā noteiktie līguma piešķiršanas kritēriji;

2) šādā metodologijā netiek ietverti elementi, kas būtu varējuši ietekmēt piedāvājumu sagatavošanu, ja tie būtu bijuši zināmi piedāvājuma sagatavošanas laikā;

3) šāda metodolog̣ija netiek pien̦emta, n̦emot vērā elementus, kas varētu diskriminējoši ietekmēt kādu no pretendentiem (Eiropas Savienïbas Tiesas 2005. gada 24. novembra spriedums lietā Nr. C-331/04 ATI EAC Srl e Viaggi di Maio Snc pret ACTV Venezia SpA, Provincia di Venezia, Comune di Venezia, 34. paragrāfs).

Iesniegumu izskatǐšanas komisija ir vairākkārt atzīmējusi, ka nacionālajām iestādēm un tiesām ir saistoša Eiropas Savienības Tiesas veiktā Eiropas Savienības tiesību interpretācija. Lai arī šì interpretācija dod pasūtîtājiem zināmu rīcības brīvību attiecībā uz vērtēšanas kritēriju vērtēšanas diapazona skaidrojuma publicēšanu, tomēr pasūtìtājiem iepirkuma dokumentācijas sastāvā būtu jāpublisko pēc iespējas plašāks informācijas apjoms.

Šì atziṇa ir īpaši svarīga, lai izvairītos no iepirkuma dokumentācijas prasību apstrīdēšanas, jo praksē bieži rodas gadījumi, ka pasūtîtājam un piegādātājiem ir atšḳirīgs skatījums uz iepirkuma procedūras dokumentācijā noteikto kritēriju precizitātes pakāpi.

Šajā sakarā var minēt piemēru no prakses (Iepirkumu uzraudzības biroja Iesniegumu izskatîšanas komisijas 2014. gada 24. aprịla lēmums Nr. 4-1.2/14-115): "Iepirkuma priekšmets ir apsardzes pakalpojumu sniegšana Izglïtības pārvaldes ēkām un pirmsskolas izglīīibas iestādēm saskaṇā ar tehnisko specifikāciju.

Iepirkuma nolikuma 6.3.1. punktā ir noteikts, ka saimnieciski visizdevīgāko piedāvājumu iepirkuma komisija izvērtēs pēc šādiem kritērijiem: P1 - mēneša abonēšanas maksa bez PVN, maksimālais punktu skaits 40; P2 - pretendenta reputācija, kas tiks vērtēta 
atbilstoši Iepirkuma nolikuma 4.5. punktā norādītajam, maksimālais punktu skaits 18; P3 - operatīvās reageēšanas laiks ne vairāk par 5 min., maksimālais punktu skaits 6; P4 - pretendentam piederošo patstāvīgi dežurējošo ekipāžu skaits pilsētā diennakts laikā, maksimālais punktu skaits 18; P5 - kvalitātes vadības sistēma atbilst ISO 9001:2008, maksimālais punktu skaits 18 .

Iepirkuma nolikuma 6.3.2.1. punktā ir noteikts, ka piedāvājuma vērtēšana notiek pēc formulas $\mathrm{S}=\mathrm{P} 1+\mathrm{P} 2+\mathrm{P} 3+\mathrm{P} 4+\mathrm{P} 5$, kur $\mathrm{S}$ - punktu kopsumma, $\mathrm{P}$ - novērtējamā kritērija punktu skaits, saskaṇā ar 6.3.1. punkta prasību.

Saskaņā ar Iepirkuma nolikuma 6.3.2.2. punktu finanšu piedāvājumi tiks vērtēti šādā veidā: viszemākajai cenai tiks pieškirts maksimālais punktu skaits, bet pārējiem piedāvājumiem punkti tiks aprēḳināti proporcionāli attiecībā pret lētāko: finansiālais novērtējums = zemākā cena / piedāvājuma cena $\times$ cenas kritērija īpatsvars.

Atbilstoši Iepirkuma nolikuma 6.3.2.3. punktam kopvērtējums katram piedāvājumam tiks iegūts: kopvērtējums = tehniskā novērtējuma punkti + finansiālā novērtējuma punkti; par saimnieciski visizdevīgāko tiks atzīts piedāvājums, kurš iegūs vislielāko punktu skaitu.

Iesniedzējs uzskata, ka nepieciešams precizēt Iepirkuma nolikumu, jo nav saprotams, kādā veidā iepirkuma komisija aprēḳinās punktu skaitu pretendentiem saimnieciski visizdevīgākā piedāvājuma vērtēšanas kritērijos P2, P3, P4 un P5, kā arī iesniedzējam nav skaidrs, kā notiks vērtēšana kritērijā P2, kurā tiek vērtēts finanšu pārskats. Tāpat iesniedzējs uzskata, ka lielāks punktu skaits būtu pieškirams par finanšu piedāvājumu, nevis par tehnisko novērtējumu.

Pasūtītājs uzskata, ka saimnieciski visizdevīgākā piedāvājuma vērtēšanas kritēriji ir noteikti atbilstoši Publisko iepirkumu likuma regulējumam un tā vajadzībām. Tāpat pasūtītājs uzskata, ka pamatoti noteicis, ka par tehnisko novērtējumu pretendents saṇems lielāku punktu skaitu nekā par finanšu piedāvājumu, jo pasūtītājs vēlas saṇemt kvalitativu pakalpojumu.

Iesniegumu izskatīšanas komisija secināja, ka, ievērojot Publisko iepirkumu likumā noteikto, pasūtītāja prerogatīva ir iepirkuma procedūrā izvēlēties piedāvājuma izvēles kritēriju un saimnieciski visizdevīgākā piedāvājuma vērtēšanas kritērija gadījumā pasūtìtāja prerogatīva ir noteikt vērtēšanas kritērijus, pēc kuriem tiks noteikts saimnieciski visizdevīgākais piedāvājums un to skaitliskās vērtības. Taču, nosakot saimnieciski visizdevīgākā piedāvājuma vērtēšanas kritērijus, pasūtītājam ir jāievēro, ka saimnieciski visizdevīgākā piedāvājuma vērtēšanas kritēriji ir nosakāmi atkarībā no konkrētā līguma (Eiropas Kopienu Tiesas 2002. gada 17. septembra spriedums lietā Nr. C-513/99 Concordia Bus Finland Oy Ab pret Helsingin kaupunki, HKL-Bussiliikenne, 53. paragrāfs).

Tāpat Iesniegumu izskatî̌anas komisija secināja, ka, vērtējot piedāvājumu, vienlaikus jāievēro nosacỉjums, ka līguma slēgšanas tiesību piešḳiršanas kritērijiem ir jābūt saskan,otiem ar Iepirkuma nolikumā noteiktajām prasībām attiecībā uz dokumentiem un informāciju, ko iesniedz pretendents, jo pretējā gadījumā nav iespējams veikt efektīvu un precīzu piedāvājumu izvērtēšanu, kas ir atzīstams par vienlīdzịgas attieksmes 
pret piegādātājiem pārkāpumu, jo netiek nodrošināta iepirkuma procedūras pārredzamība un objektivitāte (Eiropas Kopienu Tiesas 2003. gada 4. decembra spriedums lietā Nr. C-448/01 EVN AG un Wienstrom GmbH pret Austrijas Republiku, 51., 52. un 72. paragrāfs).

Vienlaikus Iesniegumu izskatǐšanas komisija no pasūtītāja pārstāves paskaidrojumiem iesnieguma izskatišanas sēdē secina, ka Iepirkuma nolikumā saimnieciski visizdevīgākā piedāvājuma vērtēšanas kritērijā P2 ir pieḷauta drukas kḷūda un pretendenta reputācija tiks vērtēta nevis atbilstoši Iepirkuma nolikuma 4.5. punktam, bet gan atbilstoši Iepirkuma nolikuma 4.6. punktam.

Iesniegumu izskatišanas komisija secināja, ka izskatāmajā lietā nepastāv strīds par to, ka Iepirkuma nolikumā nav noteikts, pēc kādas metodologijas tiks pieškirti punkti saimnieciski visizdevīgākā piedāvājuma vērtēšanas kritērijos P2, P3, P4 un P5. Savukārt izskatāmajā lietā pastāv strīds par to, vai saimnieciski visizdevīgākā piedāvājuma vērtēšanas metodologija bija jāiekḷauj iepirkuma procedūras dokumentos.

Kā tas secināms no Iepirkuma nolikuma un pasūtītāja pārstāves paskaidrojumiem iesnieguma izskatî̌anas sēdē, tad saimnieciski visizdevīgākā piedāvājuma vērtēšanas kritērijā P2 tiks vērtēta pretendenta reputācija atbilstoši Iepirkuma nolikuma 4.6. punkta (Iepirkuma nolikuma 4.6. punktā ir noteikts, ka pretendentam ir jāiesniedz saraksts ar pretendenta pieredzi līdzīgu darbu veikšanā par pēdējiem diviem gadiem, norādot pakalpojuma sniegšanas vietu, apjomu, laika posmu, kurā pakalpojums sniegts, un pakalpojuma saṇēmēju) prasībām.

Iesniegumu izskatî̌̌anas komisija no lietas materiāliem un pasūtītāja pārstāves paskaidrojumiem iesnieguma izskatī̌sanas sēdē nekonstatē, kas tieši saimnieciski visizdevīgākā piedāvājuma vērtēšanas kritērijā P2 tiks vērtēts, par ko tiks pieškirti punkti un kā tiks piešksirti punkti, proti, nav konstatējams, vai tiks vērtēts pretendenta norādìto objektu skaits, apsargājamā objekta nozīmīgums, apjoms, sniegtā pakalpojuma kvalitāte, tāpat nav konstatējams, vai punkti tiks pieškirirti, pretendentu piedāvājumus savstarpēji salīdzinot, vai pēc kādas citas metodologijas.

Vienlaikus Iesniegumu izskatî̌anas komisija secināja, ka no Iepirkuma nolikuma nav konstatējams, kas pasūtītāja ieskatā Iepirkuma nolikuma 4.6. punktā būs uzskatāmi par līdzīgiem darbiem, proti, vai par līdzīgiem darbiem būs uzskatāmi jebkuri apsardzes darbi, kuros ietilpst tehniskajā specifikācijā norādītie veicamie darbi iepirkuma līguma izpildē, vai līdzīgi darbi tiks vērtēti pēc paredzamās līgumcenas, apjomiem. Turklāt, kā tas ir secināms no Iepirkuma nolikuma, tad Iepirkuma nolikuma 4.6. punktā noteiktais saraksts ar pretendenta pieredzi līdzīgu darbu veikšanā ir iesniedzams brīvā formātā un pasūtîājs nav norādījis, kā pretendentiem ir jānorāda pakalpojuma apjoms. Lỉdz ar to, nezinot, kas tiks uzskatīti par līdzīgiem darbiem un kas tieši tiks vērtēts saimnieciski visizdevīgākā piedāvājuma vērtēšanas kritērijā P2, Iesniegumu izskatîšanas komisijas ieskatā pretendentiem nav iespējams sagatavot un iesniegt piedāvājumu iepirkumā, lai iegūtu maksimālo punktu skaitu minētājā vērtēšanas kritērijā. 
Līdz ar to Iesniegumu izskatīšanas komisijas ieskatā saimnieciski visizdevīgākā piedāvājuma vērtēšanas kritērijs P2 ir atceḷams."

Pasūtītāiiem, sniedzot informāciju par iepirkuma procedūrā izvirzītajām prasībām, ir jānodrošina, lai minētā informācija būtu ne tikai atklāta, bet arī vienāda visiem pretendentiem. Diemžēl praksē ir vērojami gadījumi, ka šī nerakstītā prasība tiek pārkāpta. Kā piemēru var norādìt šādas atziṇas (Iepirkumu uzraudzības biroja Iesniegumu izskatǐšanas komisijas 2006. gada 22. septembra lēmums Nr. 4-1.2/06-155): "[..] Apkopojot visu minēto, Iesniegumu izskatīšanas komisija uzskata, ka, lai arī iepirkuma komisija SIA "[..]" iesniegto piedāvājumu ir noraidījusi pamatoti, bet AS “[..]" iesniegtais piedāvājums varēja tikt atzìts par atbilstošu konkursa nolikuma prasībām, tomēr par būtisku pārkāpumu iepirkuma procedūras norisē ir uzskatāms tas, ka pasūtītājs pretendentiem ir izsniedzis savstarpēji atšķirīgas konkursa nolikuma redakcijas, kā arī iesniegtos piedāvājumus ir vērtējis pēc atšḳirīgiem kritērijiem, pretēji tam, kā norādīts pretendentiem izsniegtajās konkursa nolikuma redakcijās, tādējādi nenodrošinot Publisko iepirkumu likuma mērḳu ìstenošanu, t. sk. atklātības principa ievērošanu, kas ietver arī pretendentu informēšanu par visām izmaiṇām konkursa nolikumā. Tā kā iesniegto piedāvājumu vērtēšana saskaṇā ar nosacỉjumiem, par kuriem nebija informēti pretendenti, nav piel̦aujama un turklāt iepirkuma apjoma izmaiņas var būtiski ietekmēt katra pretendenta kopējo piedāvāto līgumcenu, kā arī katra pretendenta piedāvājumu kopumā, iepirkuma komisijas piel̦autais pārkāpums ir uzskatāms par būtisku, bet, tā kā piel̦autā pārkāpuma novēršana konkrētās iepirkuma procedūras ietvaros vairs nav iespējama, [..] rīkotais konkurss [..] ir izbeidzams."

\section{lepirkuma komisijas sēžu protokolu izsniegšana}

Jāṇem vērā, ka ar 2017. gada 1. martu, kad stājās spēkā jaunais Publisko iepirkumu likums, būtiski ir mainījies termiņš iepirkuma komisijas sēžu protokolu izsniegšanai.

Iepriekš Publisko iepirkumu likumā nebija noteikts konkrēts termiņš iepirkuma komisijas sēžu protokolu (arī protokolu pielikumu) izsniegšanai, līdz ar to tie bija jāizsniedz saskaṇā ar Informācijas atklātības likuma 14. pantā noteiktajiem terminiiem (7, 10, 15 vai 30 dienu laikā, atkarībā no sniedzamās informācijas, informācijas sniegšanas veida un sniedzamās informācijas papildu apstrādes nepieciešamības).

Tagad pasūtītājam ir jānodrošina protokolu, kas atspoguḷo iepirkuma norisi, ziṇojuma un iepirkuma procedūras dokumentu (izṇemot piedāvājumus un pieteikumus) izsniegšana triju darbdienu laikā pēc attiecīga pieprasījuma saṇemšanas dienas.

No Publisko iepirkumu likuma 40. panta ceturtās daḷas izriet, ka pasūtitāiss neizsniedz protokolus, izṇemot piedāvājumu atvēršanas sanāksmes protokolu, kamēr notiek pieteikumu vai piedāvājumu vērtēšana. 


\section{Informēšana par iepirkuma procedūras rezultātiem}

Svarīga komponente atklātības principa nodrošināšanā ir pretendentu informēšana par iepirkuma procedūras rezultātiem. Šim informēšanas institūtam ir būtiska loma pretendentu tiesību nodrošināšanā, tajā skaitā iespējai apstrīdēt pasūtītāja pieṇemto lēmumu.

Tomēr pasūtītāja pienākums informēt piegādātājus par iepirkuma procedūras rezultātiem nevar tikt traktēts paplašināti. Šajā sakarā izskatî̌su piemēru no prakses (Iepirkumu uzraudzības biroja Iesniegumu izskatī̌̌anas komisijas 2015. gada 10. februāra lēmums Nr. 4-1.2/15-31): "Iesniedzējs norādīja, ka pasūtītāja rīcība - daḷeji informēt iesniedzēju par rezultātiem angḷu valodā (turklāt neietverot visu Publisko iepirkumu likumā noteikto informāciju) un pievienot atsevišḳus iepirkuma komisijas sēžu protokolus (kuros joprojām nav ietverts pamatojums paziṇotajam lēmumam) latviešu valodā rada pamatu šaubām par atklātu un vienlīdzīgu attieksmi, pārkāpjot Eiropas Kopienas Dibināšanas līgumā noteikto diskriminācijas aizliegumu.

Iesniegumu izskatī̌̌anas komisija konstatēja, ka pasūtītājs 2015. gada 9. janvārī nosūtỉja iesniedzējam vēstuli pa pastu angl̦u valodā, pievienojot pielikumā iepirkuma komisijas 2014. gada 14. novembra un 2015. gada 8. janvāra sēžu protokolu norakstus latviešu valodā. Atbilstoši 2014. gada 14. novembra protokolam iepirkuma komisija ir izskatījusi ekspertes E. L. ziņojumu par iesniedzēja tehnisko piedāvājumu, kurā konstatēts, ka "pretendenta iesniegtais tehniskais piedāvājums nav atbilstošs Konkursa nolikuma un 10 tehniskās specifikācijas prasībām 32 pozīcijās (skatìt arī pielikumu Nr. 2), kā arī 89 pozīcijās piedāvājums ir uzskatāms par dậeji atbilstošu un būtu precizējams". Pielikumā Nr. 2 ir pievienota iepirkuma komisijas piesaistìtās ekspertes E. L. iesniedzēja tehniskā piedāvājuma izvērtējuma tabula un ziṇojums. Atbilstoši 2015. gada 8. janvāra protokolam par uzvarētāju atzīta personu apvienība [..], kā arī ietverts paziṇojums par iepirkuma komisijas lēmuma apstrīdēšanu. Nemot vērā minēto, Iesniegumu izskatǐšanas komisija secina, ka pasūtîājs paziņojumā par rezultātiem ir ietvēris visu likumā noteikto informāciju, savukārt fakts, ka šì informācija ir sadalīta vairākos dokumentos (protokolos un to pielikumos), nevis atspoguḷota apkopotā veidā vienā vēstulē, nav uzskatāms par Publisko iepirkumu likuma pārkāpumu, jo likums neregulē paziņojuma formu, bet nosaka vienīgi paziñojumā obligāti norādāmo informāciju. N̦emot vērā minēto, iesniegumu izskatīšanas komisija secināja, ka iesniedzēja iesniegums šajā daḷā nav pamatots."

\section{Informēšana par pieṇemtā lēmuma pamatojumu}

Eiropas Savienības Tiesa 2011. gada 20. oktobra spriedumā lietā T-57/09 Alfastar Benelux SA pret Council of the European Union ir norādijusi, ka tikai punktu atspogulojums ir pārāk abstrakta forma pamatojumam, lai pretendents varētu izvērtēt 
punktu piešķiršanas pamatotību, un, ja nav piešḳirto punktu pamatojuma (informācijas par novērtēšanas procesu), ir jākonstatē, ka pretendents nav varējis izprast pieškiirtos punktus dažādo kritēriju ietvaros.

Iepirkuma komisijai, vērtējot pretendentu piedāvājumus, ne vien ir jāvadās pēc iepriekš noteiktajiem piedāvājumu vērtēšanas kritērijiem, bet arī jāspēj pamatot pieņemtā lēmuma (piešḳirto punktu skaita) atbilstību noteiktajiem piedāvājuma vērtēšanas kritērijiem, ievērojot Publisko iepirkumu likumā noteiktos atklātuma un taisnīgas attieksmes pret piegādātājiem principus.

Uzskatāms piemērs no prakses, kas apliecina, ka iepirkuma komisijai jāspēj norādīt uz izraudzitā piedāvājuma priekšrocībām atbilstīgi noteiktajai vērtēšanas metodologiijai un piešķirto punktu skaitam (Iepirkumu uzraudzības biroja Iesniegumu izskatǐšanas komisijas 2014. gada 30. jūnija lēmums Nr. 4-1.2/14-177): "Iesniegumu izskatīšanas komisija konstatēja, ka iepirkuma priekšmets ir "Sieviešu un vīriešu situācijas izpēte Latvijas lielajos uzṇēmumos”, kur pretendentam jānodrošina pasūtitājam nepieciešamais pakalpojums saskaṇā ar tehniskajā specifikācijā norādītajām prasībām. Atbilstoši Konkursa nolikuma 20.2.4.2. punktam punkti par augstu detalizācijas un atbilstības pakāpi tiks piešķirti piedāvājumiem, kuru pakalpojuma realizācijas apraksts un iesniegtā informācija precīzi norāda paredzamā nodevuma saturu un kritērijus tā akceptēšanai, piedāvātā pakalpojuma realizācija nodrošinās tehniskajā specifikācijā norādītā plānotā rezultāta sasniegšanu, darba gaitā iespējamas minimālas pretendenta piedāvāto prasību realizācijas mehānisma korekcijas; atbilstoši Konkursa nolikuma 20.2.4.3. punktam punkti par vidēju detalizācijas un atbilstības pakāpi tiks pieškirti piedāvājumiem, kuru pakalpojuma realizācijas apraksts un iesniegtā informācija norāda paredzamā nodevuma saturu un kritērijus tā akceptēšanai, bet darba gaitā būs nepieciešamas pretendenta piedāvāto prasību realizācijas mehānisma korekcijas, lai nodrošinātu atbilstîbu pasūtītāja vajadzībām un plānotajai situācijai; atbilstoši Konkursa nolikuma 20.2.4.4. punktam piedāvājums tiks atzīts par nepietiekami detalizētu, ja pakalpojuma realizācijas apraksts un iesniegtā informācija precīzi nenorāda paredzamā 10. nodevuma saturu un kritērijus tā akceptēšanai, darba gaitā būs nepieciešamas ievērojamas pretendenta piedāvāto prasību realizācijas mehānisma korekcijas, lai nodrošinātu atbilstību pasūtītāja vajadzībām un plānotajai situācijai (piem., iztrūkst atsevišḳu procesu vai to posmu realizācijas apraksti).

Iepazīstoties ar lietas materiāliem, Iesniegumu izskatī̌sanas komisija konstatē, ka iepirkuma komisijas sēdes protokolam Nr. 3 ir pievienota iepirkuma komisijas pretendentu tehniskā piedāvājuma vērtēšanas tabula, kurā par katru no Konkursa nolikuma 20.2.4.1. punktā norādīto apakškritēriju ir norādīts iepirkuma komisijas piešķirtais punktu skaits. Vienlaikus Iesniegumu izskatišanas komisija nekonstatē, ka iepirkuma komisijas locekḷi būtu vērtējuši pretendentu piedāvājumus individuāli. Tāpat Iesniegumu izskatī̌̌anas komisija nekonstatē, ka iepirkuma komisijas sēžu protokolos, ziṇojumā par iepirkuma procedūru un paziņojumā par konkursa rezultātiem būtu norādīti komentāri vai paskaidrojumi, kāpēc attiecīgajā apakškritērijā ir pieškirirts attiecīgais punktu skaits. 
Katram iepirkuma komisijas loceklim savs vērtējums ir jāpamato, norādot piedāvājuma trūkumus vai priekšrocības, kas bija izškirošas piedāvājumam pieškirto punktu izvēlē, jo pretējā gadījumā, iztrūkstot lēmuma pamatojumam, nav iespējams pārbaudìt attiecīgā lēmuma pieṇemšanas tiesiskumu. Konkrētajā gadỉjumā, iztrūkstot šādam pamatojumam, Iesniegumu izskatǐšanas komisija secināja, ka arī pretendentiem tiek liegta iespēja iepazīties ar pien̦emtā lēmuma pamatojumu, pārliecināties par tā pareizību un izvērtēt, vai ir pamats apstrīeēt pasūtītāja lēmumu.

Iesniegumu izskatǐšanas komisija secināja, ka, iztrūkstot lēmuma pamatojumam, tai nav iespējams pēc būtības izvērtēt, vai iesniedzēja tehniskajam piedāvājumam vērtēšanas kritērijos ir pamatoti piešḳirts attiecīgais punktu skaits, arī iesniegtais iesniedzēja tehniskā piedāvājuma vērtējuma pamatojums nesniedz nepieciešamo informāciju, jo tajā ir atspoguḷoti tikai viena pretendenta piedāvājuma trūkumi. Apkopojot iepriekš minēto, Iesniegumu izskatīšanas komisija uzskata, ka iesniedzēja iesniegums ir pamatots un minētie pārkāpumi novēršami, veicot atkārtotu iesniegto piedāvājumu vērtēšanu."

\section{Pretendenta pienākums sniegt informāciju}

Jāatzīmē, ka pienākums sniegt informāciju atklātības principa ievērošanas kontekstā ir ne tikai pasūtītajam, bet arī piegādātājiem. Nav piel̦aujama piegādātāju nostādne, ka iepirkuma dokumentācijā pieprasîtā informācija, kas ir nepieciešama pretendentu atlasei vai piedāvājumu vērtēšanai, nebūtu sniedzama gadījumā, ja tā ir komercnoslēpums. Šajā sakarā jāṇem vērā, ka Publisko iepirkumu likums satur mehānismus, lai pasargātu pretendentus no piedāvājumos iesniegtās informācijas pretlikumīgas izpaušanas no pasūtītāja puses. Turklāt jebkuram piegādātājam ir jāapzinās, ka, iesniedzot piedāvājumu iepirkuma procedūrā, t. i., kḷūstot par pretendentu, viṇam ir jāuzṇemas noteiktie pienākumi, to skaitā pienākums sniegt iepirkuma komisijas pieprasìto informāciju, ja šāds pieprasījums ir pienācīgi pamatots.

Uzskatāms piemērs no prakses (Iepirkumu uzraudzības biroja Iesniegumu izskatī̌̌anas komisijas 2015. gada 22. aprīḷa lēmums Nr. 4-1.2/15-95/2): "Iesniegumu izskatī̌̌anas komisija, izvērtējot iesniedzēja piedāvājumu, secināja, ka iesniedzējs ir piesaistījis atlases ekspertu G. V., jo piedāvājumam ir pievienots SIA “[..]" izsniegts apliecinājums, ka G. V. piesaistỉja minētā uzṇēmuma attīstībai privāto finansējumu 30000 eiro apmērā. No iepriekš minētā Iesniegumu izskatî̌anas komisija secina, ka ir pamatots iepirkuma komisijas secinājums, ka no minētā apliecinājuma nav iespējams konstatēt finansējuma pieškīrēju un finansējuma piesaistes laiku, kas cita starpā bija jāiesniedz iesniedzējam atbilstoši nolikuma 10.2.5. punktam, no kura izriet, ka pasūtītājs sagaida dokumentu kopijas, kuras identificē finansējuma piešksīēju, kā arī finansējuma piesaistes laiku, lai konstatētu, ka šis eksperts ir piesaistījis finansējumu tieši pēdējo triju gadu laikā. 
Iesniegumu izskatī̌̌anas komisija secināja, ka gadījumā, ja pretendents ir ieinteresēts konkrētā iepirkuma līguma slēgšanas tiesību iegūšanā, tad tam ir pienākums sniegt nolikumā noteikto informāciju, lai iepirkuma komisija šajā gadỉjumā konstatētu iesniedzēja piesaistîtā atlases eksperta atbilstību vai neatbilstību Konkursa nolikuma 10.2.5. punktam. Attiecībā uz iesniedzēja argumentu, ka konkrētais finansējuma līgums ir uzskatāms par komercnoslēpumu (kā rezultātā nav atklājama informācija par finansējuma pieškīrēju), Iesniegumu izskatīšanas komisija secināja, ka, paziṇojot par līguma slēgšanu un informējot kandidātus un pretendentus, pasūtītājs nav tiesīgs atklāt informāciju, kuru tam kā komercnoslēpumu vai konfidenciālu informāciju nodevuši citi piegādātāji. Līdz ar to iesniegumu izskatīšanas ieskatā arguments, ka attiecīgā informācija ir uzskatāma par komercnoslēpumu, nav pamats Konkursa nolikuma prasību neizpildei pēc būtỉbas, jo šajā gadījumā pasūtītājam tiek liegta iespēja pārbaudìt iesniedzēja piesaistītā eksperta precīzu atbilstību nolikuma 10.2.5. punktam, tādējādi pašam iesniedzējam liedzot pierādīt tā piesaistītā atlases eksperta atbilstību minētajai prasībai.

Turklāt iesniedzējs savā iesniegumā nenorādīja, kādā tieši veidā informācijas par finansējuma pieškīiēju izpaušana pasūtītājam var radìt būtiskus zaudējumus finansējuma pieškīirējam. Gadījumā, ja pretendents vēlas iegūt iepirkuma līguma slēgšanas tiesības, tam ir jāṇem vērā, ka pasūtîtājs pretendentu atlasi veic un kvalifikāciju vērtē saskaṇā ar konkrētās iepirkuma procedūras nolikumu. Vienlaikus tiek saglabāts pasūtītāja pienākums neizpaust komercnoslēpumu vai konfidenciālu informāciju, uz ko pretendents īpaši norāda, identificējot, kura piedāvājumā iekḷautā informācija ir uzskatāma par komercnoslēpumu vai konfidenciālu informāciju."

\section{Dokumentu nosūtīšanas veids}

Lai atklātības princips tiktu pilnīgāk ievērots, pretendents ir ne tikai jāinformē par iepirkuma komisijas pien̦emtajiem lēmumiem, bet jāinformē pēc iespējas ātrāk.

Saskaṇā ar jaunā Publisko iepirkumu likuma, kas stājās spēkā 2017. gada 1. martā, 38. panta trešo daḷu pasūtītājs izvēlas informācijas apmaiṇas līdzekḷus, kas ir vispārpieejami, lai neapgrūtinātu piegādātājam piekḷuvi iepirkumam. Pasūtītājs izvēlas tādu šajā likumā minēto dokumentu nosūtišanas veidu, kas adresātam nodrošina pēc iespējas ātru informācijas saṇemšanu. Ja informācijas apmaiṇā tiek izmantoti elektroniskie līdzekḷi, izvēlas tādus, kuri ir publiski pieejami un savietojami ar vispārlietotām informācijas un komunikācijas tehnologijām, tādējādi novēršot iespēju diskriminēt piegādātājus uz šā pamata.

Jāatzīmē, ka jau 2008. gadā (t. i., pirms devininiem gadiem) Iepirkumu uzraudzības biroja Iesniegumu izskatīšanas komisijas lēmumos bija sastopamas atziṇas par to, ka pasta sūtījumi, lai gan tie ir likumīgs informēšanas veids, ne vienmēr nodrošina Publisko iepirkumu likuma ievērošanu. Kā vienu no konkrētajiem gadījumiem var minēt šādu piemēru (Iepirkumu uzraudzības biroja Iesniegumu izskatīšanas komisijas 2008. gada 22. janvāra lēmums Nr. 4-1.2/08-29): "[..] faktiski pretendenti, t. sk. arī iesniedzējs, 
pasūtītāja pa pastu nosūtītos pazinojumus pretendentiem par cenu aptaujās pieṇemtajiem lēmumiem varēja saṇemt tikai vairākas dienas pēc paziṇojuma par iepirkuma procedūru rezultātiem publicēšanas Iepirkumu uzraudzības biroja interneta mājaslapā, jo jāṇem vērā, ka vienkāršās vēstuḷu korespondences pasta sūtījumu pārsūtīšanas laiks iekšzemē "A" klases pasta sūtījumiem bija divas darbdienas, bet "B" klases sūtỉjumiem četras darbdienas, ieskaitot darbdienu, kad sūtỉjums nodots pastā, kā arī tas, ka pasūtìtājs paziñojumus pretendentiem par cenu aptauju rezultātiem izsūtīja pirms svētku dienām.

Ievērojot iepriekš minēto, kā arī iesniegumu izskatîšanas sēdē pasūtītāja pārstāvja sniegtos paskaidrojumus, Iesniegumu izskatîšanas komisija secināja, ka pasūtītājs nav izvēlējies pietiekoši ātru paziņojumu par cenu aptauju rezultātiem nosūtišanas veidu pretendentiem (piemēram, faksa sūtījumu), kas teorētiski varēja radìt situāciju, ka pretendents pasūtîtāja izsūtîto paziņojumu par cenu aptauju rezultātiem saṇemtu tikai pēc iepirkuma līguma noslēgšanas."

\section{Secinājumi}

1. Atklātības princips ir viens no publisko iepirkumu jomas stūrakmeṇiem, kas ietekmē vairākas jomas - gan leǵitimitātes nodrošināšanu, gan konkurences nodrošināšanu, gan pretkorupcijas funkciju, gan arī sabiedrības informēšanu. N̦emot vērā minēto, ir svarīgi, lai publiskajos iepirkumos sniegtā informācija būtu skaidra, saprotama un nepārprotama.

2. Neapšaubāmi, informācijas atklātības principa tiešā iedarbība nav attiecināma uz tādiem iepirkumu līgumiem, informācija par kuriem ir atzìta par valsts noslēpumu, kā arī gadījumos, ja informācijas publiskošana varētu radīt būtisku kaitējumu valsts interešu aizsardzībai. Tomēr ikdienas praksē, kas nav saistīta ar iepriekš minētajiem gadỉjumiem, pasūtītājiem ir jācenšas nodrošināt atklātîbas principa ievērošanu pēc iespējas plašāk. Šāda pieeja ḷaus līdzsvarot pasūtītāju, piegādātāju un sabiedrības intereses.

3. Publiskajos iepirkumos būtiska nozīme ir ne tikai informācijas sniegšanas faktam kā tādam, bet arī sniegtās informācijas apjomam un saturam (plašāk Judgment of the Court (Third Chamber) of 14 April 2005. Kingdom of Belgium vs. Commission of the European Communities). Lai arī atklātibas principu publiskajos iepirkumos nevajadzētu absolutizēt, tomēr, analogiski kā valsts administrācijas darbinieki atšksirībā no privātā sektora darbiniekiem ir pakḷauti sabiedrības interesei (sk. European Data Protection Supervisor, Public Access to Documents and Data Protection, Background Paper Series, 4 Summary, July 2005), arī piegādātājiem, kuri ir iesnieguši piedāvājumu publiskajā iepirkumā, atšḳirībā no pārējiem piegādātājiem ir jārēḳinās, ka ievērojama daḷa no pasūtītājiem sniegtās informācijas var tikt publiskota, lai nodrošinātu valsts pārvaldes caurspìdīgumu un atbildỉbu. 


\section{Ensuring Transparency Principle of Public Procurement}

\section{Abstract}

The aim of the article is to analyse the principle of transparency in the public procurement of the Republic of Latvia (Transparency is concerned with the quality of being clear, obvious and understandable without doubt or ambiguity). The study is based on the laws and regulations of Latvia, including the Public Procurement Law, Decisions of the Complaints Examination Commission of the Procurement Monitoring Bureau of the Republic of Latvia. The results of the research can be used by procurement practitioners.

Keywords: public procurement, transparency.

\section{Literatūra}

1. Eiropas Kopienu Tiesas 2002. gada 17. septembra spriedums lietā Nr. C-513/99 Concordia Bus Finland $\mathrm{Oy} A \mathrm{Ab}$ pret Helsingin kaupunki, HKL-Bussiliikenne.

2. Eiropas Kopienu tiesas 2003. gada 4. decembra spriedums lietā Nr. C-448/01 EVN AG un Wienstrom GmbH pret Austrijas Republiku.

3. Eiropas Parlamenta un Padomes Regula (EK) Nr. 1049/2001 (2001. gada 30. maijs) par publisku piekluvi Eiropas Parlamenta, Padomes un Komisijas dokumentiem.

4. Eiropas Savienības Tiesas 2005. gada 24. novembra spriedums lietā Nr. C-331/04 ATI EAC Srl, Viaggi di Maio Snc pret ACTV Venezia SpA, Provincia di Venezia, Comune di Venezia.

5. Eiropas Savienības Tiesas 2008. gada 24. janvāra spriedums lietā Nr. C-532/06 Emm. G. Lianakis AE u. c. pret Dimos Alexandroupolis u. c.

6. Eiropas Savienības Tiesas 2011. gada 20. oktobra spriedums lietā Nr. T-57/09 Alfastar Benelux SA pret Council of the European Union.

7. European Data Protection Supervisor: Public Access to Documents and Data Protection, Background Paper Series, 4 Summary. European Data Protection Supervisor. July 2005. Iegūts no: https://edps.europa.eu/sites/edp/files/publication/05-07_bp_accesstodocuments_en.pdf [sk. 12.05.2017.].

8. Hare, I. Access to Governmental Information and the Judicial Process, United Kingdom Law and the Influence of Europe. Yearbook of European Law. Oxford: University Press, 2000.

9. Iepirkumu uzraudzības biroja Iesniegumu izskatī̌sanas komisijas 2006. gada 22. septembra lēmums Nr. 4-1.2/06-155. Iegūts no: https://www.iub.gov.lv/.

10. Iepirkumu uzraudzības biroja Iesniegumu izskatišanas komisijas 2008. gada 22. janvāra lēmums Nr. 4-1.2/08-29. Iegūts no: https://www.iub.gov.lv/ [sk. 12.05.2017].

11. Iepirkumu uzraudzības biroja Iesniegumu izskatīšanas komisijas 2008. gada 1. decembra lēmums Nr. 4-1.2/08-469. Iegūts no: https://www.iub.gov.lv/ [sk. 12.05.2017.].

12. Iepirkumu uzraudzïbas biroja Iesniegumu izskatī̌sanas komisijas 2009. gada 22. decembra lēmums Nr. 4-1.2/09-472/2. Iegūts no: https://www.iub.gov.lv/ [sk. 12.05.2017.]. 
13. Iepirkumu uzraudzības biroja Iesniegumu izskatī̌̌anas komisijas 2014. gada 24. aprīla lēmums Nr. 4-1.2/14-115. Iegūts no: https://www.iub.gov.lv/ [sk. 14.05.2017.].

14. Iepirkumu uzraudzības biroja Iesniegumu izskatīšanas komisijas 2014. gada 30. jūnija lēmums Nr. 4-1.2/14-177. Iegūts no: https://www.iub.gov.lv/ [sk. 14.05.2017.].

15. Iepirkumu uzraudzības biroja Iesniegumu izskatīšanas komisijas 2015. gada 10. februāra lēmums Nr. 4-1.2/15-31. Iegūts no: https://www.iub.gov.lv/ [sk. 14.05.2017.].

16. Iepirkumu uzraudzības biroja Iesniegumu izskatīšanas komisijas 2015. gada 22. aprīla lēmums Nr. 4-1.2/15-95/2. Iegūts no: https://www.iub.gov.lv/ [sk. 14.05.2017.].

17. Judgment of the Court (Third Chamber) of 14 April 2005. Kingdom of Belgium vs. Commission of the European Communities.

18. Lewis, C. Linkage between Access to Information and Judicial Review. Freedom of Expression and Freedom of Information. Oxford: Oxford University Press, 2000, 289-298.

19. Sabiedrības par atklātību - Delna pētījums "Informācijas pieejamība valsts un pašvaldību iestādēs”. Informāciju apkopojusi Diāna Kurpniece. Rīga, 2000. gada februāris, 5. lpp. Iegūts no: http://info-a.wdfiles.com/local--files/resursi/FOIA\%20LV\%20report\%202000 [sk. 14.05.2017.]. 